\title{
PELAKSANAAN SASARAN KESELAMATAN PASIEN PENDERITA SERANGAN JANTUNG
}

\author{
ANGEL OKTAVIA PURBA / 181101099 \\ angeloktavia013@gmail.com
}

\begin{abstract}
ABSTRAK
Keselamatan pasien merupakan suatu hal yang sangat penting diperhatikan dalam suatu Rumah Sakit. Keselamatan pasien adalah suatu sistem dimana Rumh sakit memberikan asuhan kepada pasien secara aman serta mencegah terjadinya cideraa akibat kesalahan karena melakukan karena melakukan suatu tindakan atau tidak melakukan suatu tindakan. Adapun tujuan dari penulisan ini adalah untuk mengetahui apa itu keselamatan pasien atau patient safety, mengetahui apa tujuan patien safety dan untuk mengetahui bagaimana pelaksanaa sasaran keselamatan pasien misalnya pada pasien penderita serangan jantung. Metode penulisan ini adalah Literature Riview, dimana ini menganalisis artikel yang relevan dan berfokus pada tema Pelaksanaan sasaran keselamatan pasien.
\end{abstract}

\begin{abstract}
Patient Safety is a very important thing in the Hospital. Patient safety is a system where Rumh sick gives patients to be safe to prevent injury from causing errors due to an action or not taking action. What are the goals of patient safety, patient safety, patient safety, patient safety, patient safety, patient safety, patient safety This method of return is the Riview Literature, where it analyzes relevant articles and is discussed on the theme of Patient Safety Implementation.
\end{abstract}

Kata Kunci : Patient safety, Tujuan keselamatan pasien, Sasaran Keselamatan Pasien

\section{LATAR BELAKANG}

Keselamatan pasien merupakan suatu hal yang sangat penting diperhatikan dalam suatu Rumah Sakit. Keselamatan pasien adalah suatu sistem dimana Rumh sakit memberikan asuhan kepada pasien secara aman serta mencegah terjadinya cideraa akibat keslahan karena melakukan karena melakukan suatu tindakan atau tidak melakukan suatu tindakan. Keselamatan pasien adalah hal terpenting yang perlu diperhatikan oleh setiap petugas medis yang terlibat dalam memberikan pelayanan kesehatan kepada klien. Tindakan pelayanan, peralatan sehatan, 
dan lingkungan sekitar pasien sudah seharusnya menunnjangn keselamatan serta kesembuhan dari pasien. Oleh karena itu tenaga medis baik perawat harus memiliki pengetahuan dan skill mengenai haj pasien serta mengetahui secara luas dan teliti setiap tindakan yang dapat menjaga keselamatan pasien. Setiap tindakan pelayanan kesehatan yang diberikan kepada pasien seharusnya memberi dampak positif agar tidak menimbulkan kerugian bagi pasien. Untuk menghindari hal yang demikian piha Rumah sakit harus memiliki standart tertentu dalam memberikan pelayanan kesehatan kepada pasien. Standartt tersebut bertujuan untuk melindungi hak pasien dalam mendapatkan pelayanan dan asuhan kesehatan kepada pasien.

\section{TUJUAN}

Adapun tujuan dari penulisan ini adalah untuk mengetahui apa itu keselamatan pasien atau patient safety, mengetahui apa tujuan patien safety dan untuk mengetahui bagaimana pelaksanaa sasaran keselamatan pasien misalnya pada pasien penderita serangan jantung.

\section{METODE}

Metode penulisan ini adalah Literature Riview, dimana ini menganalisis artikel yang relevan dan berfokus pada tema Pelaksanaan sasaran keselamatan pasien. Adapun artikel yang digunakan dalam literature ini menggunakan sumber dari buku teks, jurnal dengan memasukan kata kunci. Pelaksanaan sasaran keselamatan pasien .Adapun jurnal yang saya yang digunakan merupakan jurnal yang diiterbitkan pada 10 tahun terakhir.

\section{HASIL}

Berdasarkan pencarian literature didapatkan pengertian patien safety atau keselamatan pasien, apa saja tujuan sistem patient safety, Mengetahui bagaimana pelaksanaan sasaran keselamatan pasien di rumah sakit, dan mengetahui bagaimana pelaksanaa sasaran keselamatan pasien misalnya pasien penderita serangan jantung.

\section{PEMBAHASAN}

Keselamatan pasien merupakan sistem yang bertujuan untuk memberikan asuhan terhadap pasien secara aman sebagai upaya mencegah kejadian yang tidak diinginkan (Kemenkes, 2011). Banyaknya jenis obat, jenis 
pemeriksaan dan prosedur, serta jumlah pasien dan staf rumah sakit yang cukup besar, merupakan hal yang berpotensi terjadinya kesalahan dalam proses pemberian pelayanan kesehatan berupa kesalahan diagnosis, pengobatan, perawatan, serta kesalahan sistem lainnya sehingga berbagai kesalahan yang terjadi mengakibatkan insiden keselamatan pasien. Seluruh tindakan medis terhadap pasien pasti memiliki risiko tersendiri. Pastinya tidak ada satu petugas kesehatan atau dokter pun yang menginginkan pasiennya mengalami risiko tidak diinginkan tersebut. Oleh sebab itu, keselamatan pasien harus diutamakan dalam setiap penanganan medis. Setiap tenaga medis harus memahaminya, sehingga bisa menerapkannya dengan baik. Keselamatan pasien adalah kunci penting bagi setiap fasilitas kesehatan. Hal ini pula yang menjadi indikator sangat penting dalam penilaian sebuah rumah sakit. Terutama dalam kepentingan akreditasinya sebagai standar mutu atas pelayanan dan kinerjanya. Untuk menjamin hal tersebut, maka sudah ditetapkan 6 sasaran keselamatan pasien.

\section{KETEPATAN IDENTIFIKASI}

\section{PASIEN}

Hal ini untuk mengembangkan pola pendekatan agar bisa meningkatkan atau memperbaiki ketelitian dalam identifikasi pasien. Aplikasinya seperti identifikasi sebelum pemberian atau pengambilan darah, konsumsi obat dan tindakan lainnya.

Salah satu pendukung poin ini adalah penggunaan gelang identitas pasien.

\section{PENINGKATAN KOMUNIKASI}

\section{EFEKTIF}

Cara ini untuk mengembangkan pola pendekatan agar komunikasi bisa berjalan dengan efektif. Hal ini bertujuan agar komunikasi lisan terjadi dengan akurat, sehingga informasinya bisa diterapkan secara konsisten.

\section{PENINGKATAN KEAMANAN} OBAT ATAU HIGH ALERT YANG HARUS DIWASPADAI

Cara ini dilakukan agar memastikan obat tetap aman untuk diberikan kepada pasien. Prosedur ini berkaitan dengan proses identifikasi, pemberian label, penetapan lokasi dan penyimpanannya.

\section{KEPASTIAN TERHADAP}

LOKASI, PROSEDUR DAN PASIEN OPERASI 
Cara ini diaplikasikan agar pasien tercatat dengan valid sebelum mendapatkan tindakan operasi.

\section{PENGURANGAN TERHADAP} RISIKO INFEKSI SETELAH MENGGUNAKAN PELAYANAN KESEHATAN

Hal ini adalah prosedur dalam pencegahan penyakit menular dan infeksi sesuai dengan pedomannya.

\section{PENGURANGAN RISIKO JATUH}

Setiap tenaga medis harus memahami dan mengaplikasikan sejumlah langkah untuk memastikan pasien tidak mengalami risiko jatuh. Semua langkah akan diawasi untuk memastikan keberhasilannya. Dengan begitu segala risiko tersebut tidak akan menimpa pasien yang tengah dirawatnya.

\section{KESIMPULAN}

Patient safety atau keselamatan pasin adalah prinsip dasar dari perawatan kesehatan (WHO). Patient safety merupakan suatu upaya mencegah, menghindari dan memperbaiki hasil yang merugikan pasien atau cidera akibat dari proses memberikan pelayanan kesehatan (US National Safety Fuondation,1999).Terdapat 6 sasaran keselamata pasien yaitu :
- Ketepatan Identifikasi Pasien.

- Peningkatan Komunikasi Efektif.

- Peningkatan Keamanan Obat Yang Perlu Diwaspadai.

- Kepastian terhadap lokasi, prosedur dan pasien operasi.

- Pengurangan Resiko Infeksi Terkait Pelayanan Kesehatan.

- Pengurangan Resiko Pasien Jatuh.

\section{SARAN}

Setiap tindakan pelayanan kesehatan yang diberikan kepada pasien sepatutnya memberi dampak yang positif sehingga tidak memberikan kerugian pada pasien. Dalam pelaksanaan sasaran keselamatan pasien harus sepenuhnya dilaksanakan dengan baik dan benar serta pengetetahuan perawat juga sangat penting dalam pelaksanaan sasaran keselamatan pasien.

\section{DAFTAR PUSTAKA}

Aruum,Diah, dkk. (2015) Pengetahuan

Tenaga Kesehatan Dalam Sasaran

Keselamatan Pasien Di Rumah Sakit

Sumatera Utara. Idea Nursing Journal, Vol 6(2).

Asmandi. (2008). Konsep Dasar

Keperawatan. Jakarta : EGC. 
Azrul, A. (1996). Menuju Pelayanan

Kesehatan Yang Bermutu. Jakarta :

Salemba Medika.

Dapartemen Kesehatan RI. (2008).

Upaya Peningkatan Mutu Pelayanan

Rumah sakit. Jakarta : Depkes RI.

Firawati. (2012). Pelaksanaan Program

Keselamatan Pasien di RSUD Solok.

Jurnal Kesehatan Masyarakat, Vol 6,

No 2.

Gede, Muninjaya A.A. (2011).

Manajemen Mutu Pelayanan Kesehtan.

Jakarta : EGC.

Hakim, Lukman.,Widodo,J. (2014).

Optimalisasi Proses Koordinasi

Program Keselamatan Pasien

(Patient Safety) Di Rumah Sakit.

Jurnal Administrasi Kesehatan

Indonesia. 198-208.

Harus, B. D.(2015). Pengetahuan

Perawat Tentang Keselamatan Pasien dengan Pelaksanaan Prosedur

Keselamatan Pasien Rumah Sakit

(KPRS) di Rumah Sakit Panti Waluyu

Sawahan Malang. Jurnal CARE, Vol 3, No1.
Potter \& Perry.(2005). Fundamental

Keperawatan : Konsep Proses dan

Praktek. Jakarta : Salemba Medika.

Roper, Nancy. (1996). Prinsip-Prinsip

Keperawatan. Yogyakarta : Andi

Yayasan Essentia Medica.

R.H Simamora. (2019). Buku Ajar

Pelaksanaan Identifikasi Pasien:

Uwais Inspirasi Indonesia.

R.H. Simamora. (2019). Documentation Of Patient Identification Into The Electronic System to Improve the Quality of Nursing Service. Internasional Journal Of Sciiebtific \& Technology Research, Vol 08(09),18841886.

R.H. Simamora. (2019). The Influence Of Training Handover Based SBAR Communication For Improving Patients Safety. Indian Journal Of Public Health Research \& Development, Vol 09, 1280-1285.

Sumarni. (2017). Analisis Implementasi Patient Safety Terkait Peningkatan Mutu Pelayanan Kesehaatan di RS. Jurnal Ners dan Kebidanan Indonesia. 91-99. 
